\title{
Mining Waste Volume Estimation Using Airborne Lidar Data and Historical Maps: A Case Study of Tailing Piles in Szklary, Lower Silesia $^{\dagger}$
}

\author{
Paweł Trybała ${ }^{1}$, Wojciech Kaczan ${ }^{2, * \mathbb{C}}$ and Adam Górecki ${ }^{1}$ \\ 1 Department of Geodesy and Geoinformatics, Wrocław University of Science and Technology, ul. Na Grobli 15, \\ 50-421 Wrocław, Poland; pawel.trybala@pwr.edu.pl (P.T.); adam.gorecki@pwr.edu.pl (A.G.) \\ 2 Department of Mining, Wrocław University of Science and Technology, ul. Na Grobli 15, \\ 50-421 Wrocław, Poland \\ * Correspondence: wojciech.kaczan@pwr.edu.pl \\ + Presented at the Innovations-Sustainability-Modernity-Openness Conference (ISMO'21), Bialystok, Poland, \\ 14 May 2021.
}

Citation: Trybała, P.; Kaczan, W.; Górecki, A. Mining Waste Volume Estimation Using Airborne Lidar Data and Historical Maps: A Case Study of Tailing Piles in Szklary, Lower Silesia. Environ. Sci. Proc. 2021, 9, 32. https://doi.org/10.3390/ environsciproc2021009032

Academic Editors: Dorota Anna Krawczyk and Antonio Rodero Serrano

Published: 12 November 2021

Publisher's Note: MDPI stays neutral with regard to jurisdictional claims in published maps and institutional affiliations.

Copyright: (C) 2021 by the authors. Licensee MDPI, Basel, Switzerland. This article is an open access article distributed under the terms and conditions of the Creative Commons Attribution (CC BY) license (https:// creativecommons.org/licenses/by/ $4.0 /)$.

\begin{abstract}
Reliable feasibility analysis of potential exploitation of a mining waste deposit poses a great challenge. One of the most crucial parts of this process is the approximation of the deposit volume. In this case study we propose a novel method of tailing pile volume estimation using open remote sensing and cartographic data. For selected piles, the difference between the proposed and classical approach reach $50 \%$ of the pile volume, which is a significant change in the potential value of the deposit.
\end{abstract}

Keywords: tailing piles; slag piles; volume estimation; Szklary; nickel; airborne LiDAR

\section{Introduction}

The importance of mining waste analyses is highlighted by their environmental impact and the potential of the raw materials. This attention is highly visible in commercial and scientific activities within Europe and the world [1]. In Poland, the discussion about the mineralization potential and the environmental impact of tailing piles and tailing ponds has been a point of interest for many years. The significance has its grounding in a large number of recognized tailing piles in Poland. The Polish Geological Institute has recognized, in the last few years, more than 568 objects within the Sudetes and neighboring territories [2,3]. One of the main features of those objects for potential investors is the actual volume. Because of the development of remote sensing, cartographers have better and faster tools for the modeling of the surface. The improvement is sped up by the wider use of drone-borne measurements. However, among those techniques, there is still no tool for the precise modeling of the bottom surface of historically man-made morphological forms. The common techniques for that purpose use linear fit (flat surface), the lowest point (lowest point of the contour treated as a reference elevation) and triangulation (points of contour joined using the triangulation algorithm) [4]. Moreover, the drone-borne measurements require fieldwork and are still expensive if there is a need for the use of LIDAR sensors. In 2020 the airborne LiDAR data, with a resolution of $1 \mathrm{~m}$, which covers the whole territory of Poland, was made public [5]. Airborne LiDAR data, thanks to its availability in Poland and its accuracy, is a dataset commonly used by geologists and geological cartographers [6].

The article proposes the methodology of tailing piles volume estimation with the use of LiDAR data. Moreover, thanks to the publicly available historical maps, we introduce an element of base surface interpretation. All of that results in the coherent methodology for the no expense, fast and accurate mining waste volume estimation.

The authors decided to choose the area of Szklary as a test field for the proposed methodology due to its varied terrain, significance in terms of the environmental impact 
and raw materials potential. The study takes into account 13 tailing piles in this area. Three of them are composed of slags and ten are built of the waste rock [7]. The authors believe that the chosen example is representative of diverse forms of tailing piles present in Poland and other parts of Europe.

\section{Research Area}

The Szklary massif is the geological and physico-geographical unit situated $7 \mathrm{~km}$ at north from Zabkowice Śląskie. Morphologically, it is a hill range Wzgórza Szklarskie (microregion) which comprises four hills: Siodłowe, Szklana Góra, Tomickie, Koźmickie. The Szklary massif is built with serpentines. The weathering of serpentines between the Oligocene and Miocene resulted in the creation of nickel ore. Moreover, the region is known for its nickel deposit and the occurrence of minerals like chrysoprase, opal and chalcedony [8]. The mining activity in this region started in the late 19th century. Before the World War I, exploitation was only carried out with the underground method, but with time, the method was changed to open-pit mining. After World War II, open-pit exploitation was started by polish mining enterprises and operated until 1982. The closure was related to the low content of nickel in the ore, inefficient processing technology (pyrometallurgy) and environmental aspects (especially dusting). The whole mining activity resulted in the changed morphological form of this region. Those structures remaining are numerous open-pits, shafts, adits, tailing piles and slag piles [9]. All of the mentioned waste disposed in this region is not yet included in the geodatabase Hałdy [2]. The analyzed tailing piles and the area of study are shown in Figure 1.

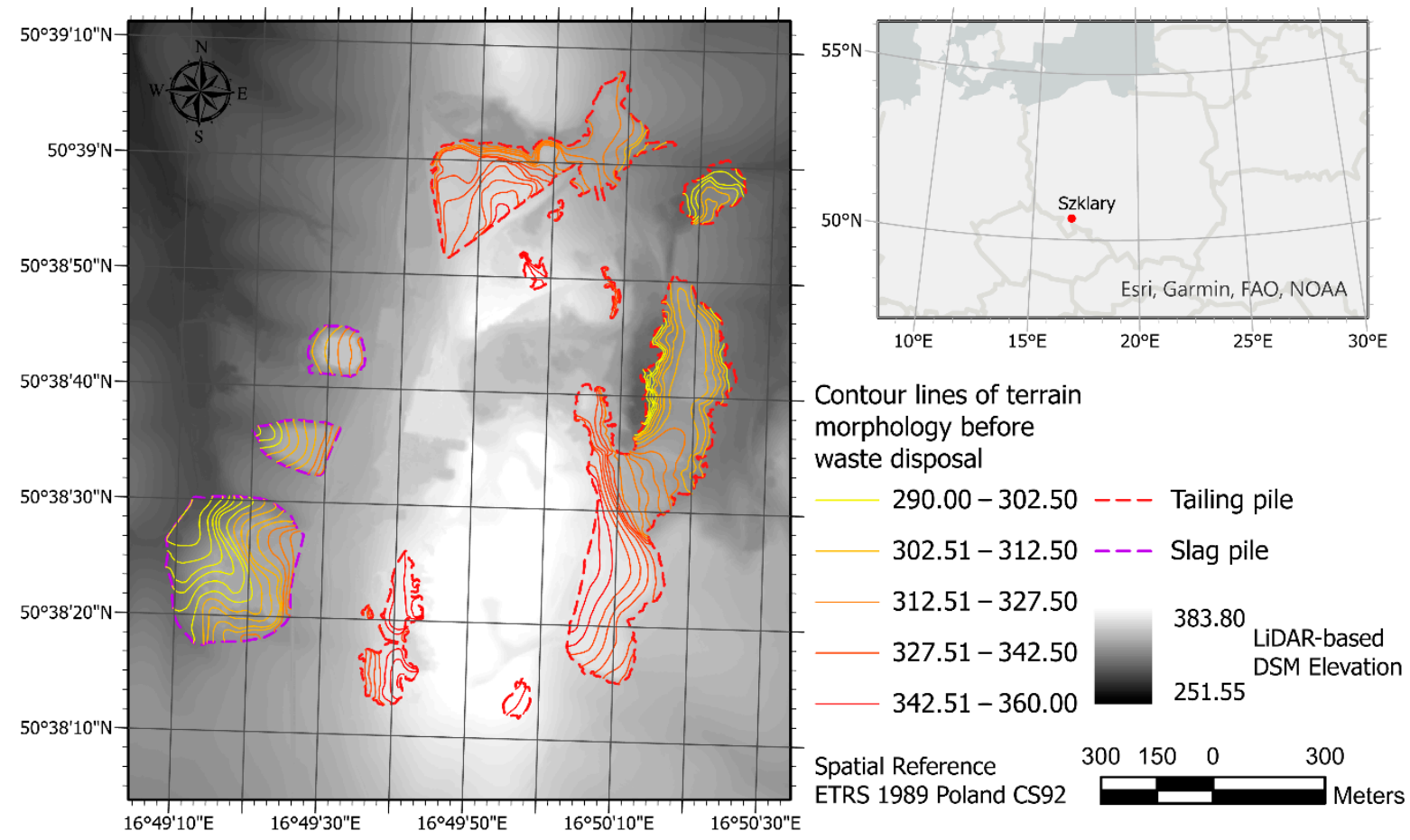

Figure 1. Locations of the area of study and tailing piles in Szklary, Lower Silesia, Poland.

\section{Materials and Methods}

The study is mainly based on 2 reliable cartographic sources. The historical information can be found on Messtischblätter (1880-1945)— the topographic maps of the German Empire, which have a scale of 1:25,000 [10]. The Messtichblatter is the most detailed historical source of the information about topography in this part of Europe. This map creation time allows the study of the terrain morphology before or during historical mining activities. An additional advantage is the fact that the topography of the area was presented 
using contour lines [10]. This map is also publicly available because all its scans have been published on the Internet and are free of charge.

The second data source is the LiDAR-based Digital Surface Model (DSM), which is a free-of-charge, publicly available dataset published online by the Polish Head Office of Geodesy and Cartography (GUGiK) on the national geoportal website. A raster dataset, created from point clouds acquired with Aerial Laser Scanning (ALS) with a cell size of $1 \mathrm{~m}$ and vertical accuracy of up to $20 \mathrm{~cm}$, has been used to represent the current geometry of the tailing piles' surface.

The contours of tailing piles have been manually interpreted from the LiDAR hillshade map, soil maps (1:000), geological maps (1:25,000) and Messtischblätter (1:25,000). However, this was necessary only because they are not yet present in the previously mentioned Polish tailing pile spatial database, maintained by the Polish Geological Institute.

The proposed methodology for improving the accuracy of mining waste volume estimation consists of a few steps. Firstly, historical contour lines, representing the original terrain shape before the creation of the pile, have been drawn through digitization of the archival topographical maps. Contour lines are then used, together with the current borders of the pile, to create a triangular irregular network (TIN). The TIN is then transformed into an elevation raster dataset, describing the geometry of the bottom of the pile. Afterward, it is compared to the LiDAR-based DSM of the present terrain surface, and their difference is calculated to obtain the volume of the tailing pile, and the final reports are created. The workflow has been automated in ArcGIS Pro software with the use of the Model Builder tool. Its graphical representation is shown in Figure A1 in Appendix A.

\section{Results and Discussion}

Volume estimates were obtained for 13 tailing piles in the area of study using two methods of base surface estimation. For the first one, the original terrain surface, before waste disposal, was estimated with the traditional method using the current elevation of the pile border points derived from LiDAR and creating a TIN model from them. The latter consists of approximating the bottom of the tailing piles using original terrain surface interpreted from the contour lines drawn on the historical maps. Examples of $3 \mathrm{D}$ visualizations of the resulting base surfaces for one of the tailing piles are shown in Figure 2. The actual surface of the piles was obtained from the LiDAR data in both cases.
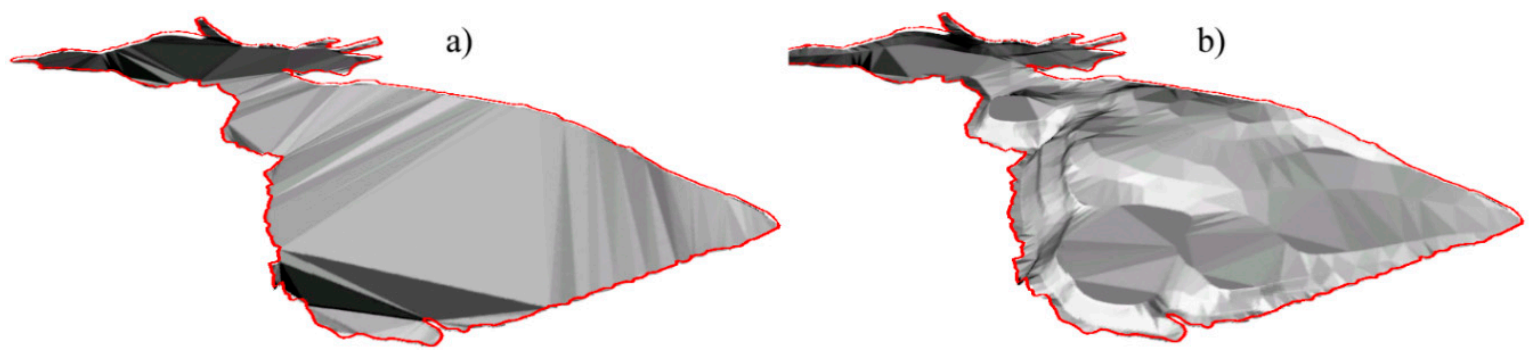

Figure 2. Shaded 3D visualizations of base terrain surface reconstructions: (a) TIN created from LiDAR contour points; (b) TIN based on historic topographic data.

The obtained results show that, for some areas where mining waste has been disposed, the original terrain cannot be approximated by a TIN created from the pile border points. While in a few cases, this approach provided similar results to our methodology, in extreme cases, the volume was overestimated by more than $50 \%$ or underestimated by over $40 \%$ compared to the proposed method. This shows that the former method can be unreliable for mining waste volume estimation, especially in varied terrain. While novel methodology, presented in this study, needs more data describing the original surface shape, e.g., in the form of contours from historical maps, this data often exists and can be easily acquired to seamlessly increase the reliability and accuracy of mining waste volume estimation. Such data has been also used previously in the mining context for different purposes [11], 
which further proves its accessibility and together with our study, demonstrates the value of historic materials in modern calculations regarding present matters.

Author Contributions: Conceptualization, P.T., W.K. and A.G.; Methodology, P.T., W.K. and A.G.; Software, P.T.; Formal analysis, P.T.; Investigation, A.G., P.T. and W.K.; Resources, W.K. and A.G.; Supervision, A.G.; Validation, W.K. and A.G.; Visualization, P.T.; Writing-original draft preparation, W.K. and P.T.; Writing — review and editing, A.G. All authors have read and agreed to the published version of the manuscript.

Institutional Review Board Statement: Not applicable.

Informed Consent Statement: Not applicable.

Data Availability Statement: Publicly available dataset was analyzed in this study. LiDAR data can be found here: https://mapy.geoportal.gov.pl/.

Acknowledgments: The research was supported by the statutory grant at the Department of Geodesy and Geoinformatics, Faculty of Geoengineering, Mining and Geology, Wroclaw University of Science and Technology.

Conflicts of Interest: The authors declare no conflict of interest.

\section{Appendix A}

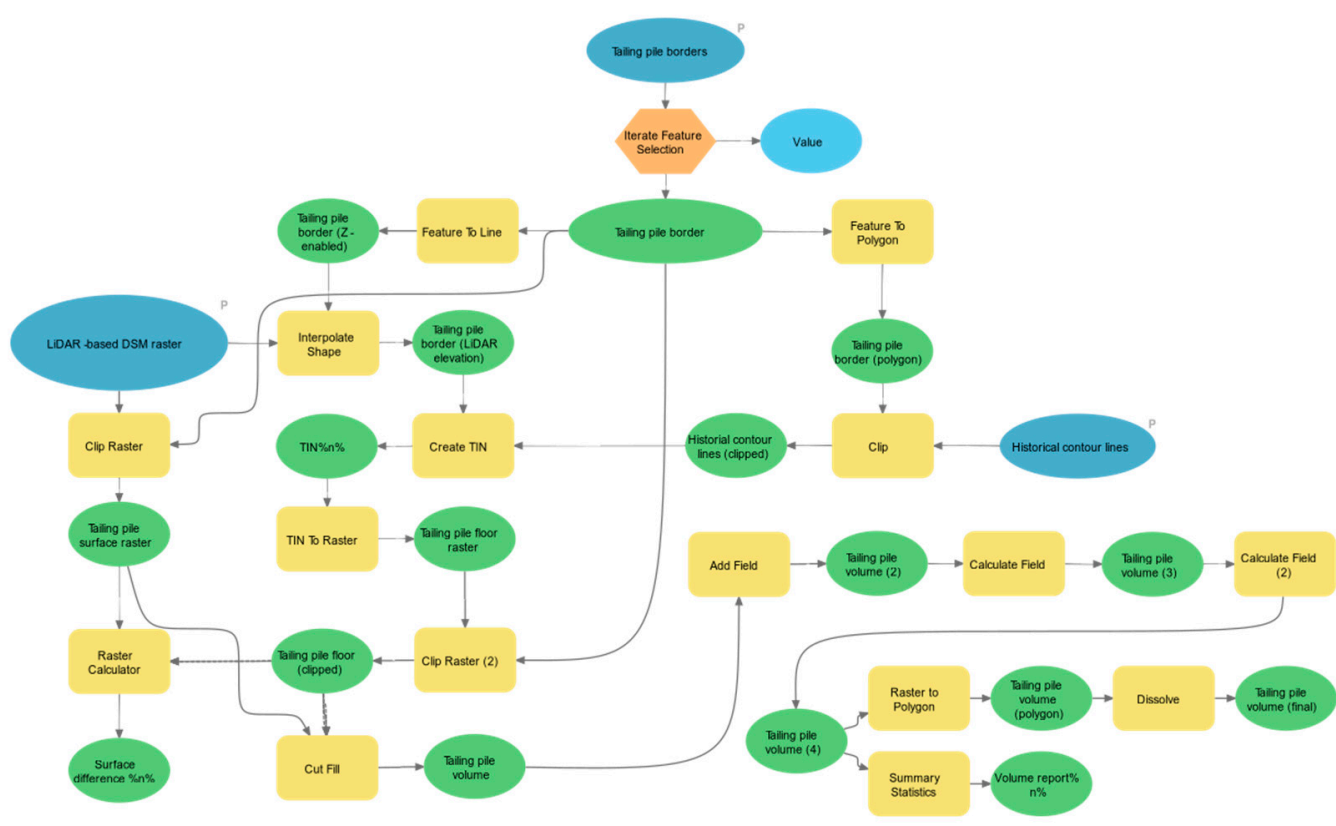

Figure A1. Workflow of tailing pile volume estimation developed in ArcGIS Pro Model Builder.

\section{References}

1. Suppes, R.; Heuss-Aßbichler, S. Resource Potential of Mine Wastes: A Conventional and Sustainable Perspective on a Case Study Tailings Mining Project. J. Clean. Prod. 2021, 297, 126446. [CrossRef]

2. Geodatabase Hałdy-Odpady Wydobywcze i Przemysłowe. Available online: https://cbdgportal.pgi.gov.pl/haldy/ (accessed on 29 March 2021).

3. Sroga, C.; Mikulski, S.Z.; Bobiński, W.; Adamski, M. Stare hałdy w Sudetach—nowa geobaza Państwowego Instytutu Geologicznego. Zesz. Nauk. Inst. Gospod. Surowcami Miner. Pol. Akad. Nauk 2018. [CrossRef]

4. Kaamin, M. Volumetric Change Calculation for a Landfill Stockpile Using UAV Photogrammetry. Int. J. Integr. Eng. 2019, 11, 053-062.

5. Polish Head Office of Geodesy and Cartography (GUGIK). Numerical Elevation Models. Available online: https://www. geoportal.gov.pl/en/dane/numeryczne-modele-wysokosciowe (accessed on 29 March 2021).

6. Kowalski, A.; Maciejak, K.; Wojewoda, J.; Kozłowski, A.; Raczyński, P. Antropogeniczne zmiany rzeźby na terenach górniczych Starego Zagłębia Miedziowego (synklinorium północnosudeckie) w świetle analiz geomorfometrycznych NMT LiDAR i danych archiwalnych. Biul. Państwowego Inst. Geol. 2017, 24. (In Polish) [CrossRef] 
7. Kaczan, W.; Wirth, H. Preliminary Analysis of Szklary Deposit (SW Poland) in the Aspect of Critical Metals Occurrence with Respect to the Circular Economy. AIP Conf. Proc. 2020, 2209, 030001. [CrossRef]

8. Niśkiewicz, J. Budowa geologiczna masywu Szklar (Dolny Śląsk). Rocz. Pol. Tow. Geol. 1967, XXXVII, $387-418$.

9. Furmankiewicz, M.; Krzyżanowski, K. Podziemne Relikty Kopalni Niklu w Szklarach. In Dzieje Górnictwa—Element Europejskiego Dziedzictwa Kultury; Oficyna Wydawnicza Politechniki Wrocławskiej: Wrocław, Poland, 2008; Volume I, pp. 51-60. (In Polish)

10. Panecki, T. Koncepcja Struktury Bazy Danych Historycznych Obiektów Topograficznych. Ph.D. Thesis, University of Warsaw, Warsaw, Poland, 2018. (In Polish)

11. Gawior, D.; Rutkiewicz, P.; Malik, I.; Wistuba, M. Contribution to understanding the post-mining landscape-Application of airborn LiDAR and historical maps at the example from Silesian Upland (Poland). AIP Conf. Proc. 2017, 1906, 170017. [CrossRef] 